\title{
PERAN PENDIDIKAN SEBAGAI MESIN PERTUMBUHAN EKONOMI MASYARAKAT
}

\author{
Syafaruddin Munthe \\ Univa Labuhan Batu, Sumatera Utara \\ Email: smfmunthe@gmail.com
}

\begin{abstract}
The Challenge Of Developing Education Is To Improve Quality Education Services To Create Human Resources According To The Demands Of The 21st Century. Every Tertiary Institution Must Direct Learning Patterns Guided By The Vision Of 21st Century Education, Including: Learning To Think, Learning To Do, Learning To Live Together, And Learning To Be. With This Guideline, University Graduates Must Be Able To Harmonize Their Product / Service Products According To The Movement Of The 21st Century That Moves Very Quickly With The Characteristics Of The Use Of Information Technology. University Graduates Must Be Able To Produce Competent And Highly Competitive Products Without Knowing The Marketing Area.
\end{abstract}

Keywords: The Role Of Education, The Engine Of Economic Growth

\begin{abstract}
Abstrak
Tantangan Pembangunan Pendidikan Adalah Meningkatkan Pelayanan Pendidikan Berkualitas Untuk Menciptakan Sumberdaya Manusia Sesuai Tuntutan Abad 21. Setiap Perguruan Tinggi Harus Mengarahkan Pola Pembelajaran Berpedoman Visi Pendidikan Abad 21, Meliputi: Learning To Think, Learning To Do, Learning To Live Together, Dan Learning To Be. Dengan Pedoman Ini, Tamatan Perguruan Tinggi Harus Dapat Menyelaraskan Produk Barang/ Jasa Ciptaannya Sesuai Pergerakan Abad 21 Yang Bergerak Sangat Cepat Dengan Bercirikan Pemanfaatan Teknologi Informasi. Tamatan Perguruan Tinggi Harus Dapat Menghasilkan Produk Yang Kompoten Dan Berdaya Saing Tinggi Tanpa Mengenal Kawasan Pemasaran.

Kata Kunci: Peran Pendidikan, Mesin Pertumbuhan Ekonomi
\end{abstract}

\section{PENDAHULUAN}

Tantangan Pembangunan Pendidikan Adalah Meningkatkan Pelayanan Pendidikan Yang Berkualitas Sesuai Tuntutan Abad 21. Abad Ini Ditandai Dengan Munculnya Era Informasi, Yakni Era Yang Serba Digital. Semua Bentuk Pendidikan Dapat Diakses Secara Mudah Melalui Gadget, Baik Itu Materi Kuliah Secara Tertulis Maupun Penjelasan Menggunakan Versi Video Di Website. Kondisi Ini, Mengharuskan Setiap Pengajar Melakukan Inovasi Pembelajaran Di Kelas. Tidak Ada Lagi Metode Ceramah Berupa Mencatat Isi Buku/Materi Kuliah Di Depan Kelas, Tetapi Harus Digantikan Dengan Metode Pembelajaran Yang Inovatif. Yaitu Metode Pembelajaran Yang Merangsang Mahasiswa Untuk Belajar Mandiri, Dan Memberikan Tantangan Kepada Setiap Mahasiswa Untuk Menyelesaikan Permasalahan Belajar Yang Dihadapinya.

Susilo (2011) Menyatakan Ada Empat Pembelajaran Yang Dibutuhkan Di Abad 21, Yaitu: Menekankan Pada Matakuliah Utama, Menekankan Pada Pengembangan Keterampilan Belajar, Memanfaatkan Alat Belajar Abad 21, Dan Membelajarkan Mahasiswa Sesuai Konteks Abad 21. Dari Segi Pemanfaatan Alat Belajar, Setiap Pendidik Sedapatkan Mungkin Menyandingkan Teknologi (It) Dalam Setiap Pembelajaran Di Kelas. Mahasiswa Dituntut Untuk Mengembangkan Pengetahuan Awalnya
Dengan Mencermati Berbagai Hal Yang Ada Di Masyarakat, Melalui Gadget Atau Komputer Kampus. Dengan Pola Ini Diharapkan Setiap Mahasiswa Memiliki Pengetahuan Terdepan, Yang Sesuai Dengan Kebutuhan Tenaga Terampil Di Masyarakat.

Untuk Itu Menjadi Perhatian Penting Bagi Setiap Perguruan Tinggi Untuk Menyiapkan Tamatan (Sumberdaya Manusia) Yang Terampil, Baik Dari Sisi Pengetahuan Maupun Keterampilan. Sisi Pengetahuan Yang Diperoleh Selama Duduk Di Bangku Kuliah Dan Hasil Penelusuran Internet, Yang Sesuai Dengan NilaiNilai Kebenaran. Sisi Keterampilan Menjadi Bagian Tidak Terpisahkan Dari Upaya Perguruan Tinggi Menciptakan Sumberdaya Mumpuni Yang Akan Mendari Roda Pengerak Pembangunan Bangsa.

\section{METODE PENELITIAN Ekonomi Dan Pekerjaan Baru}

Banyak Pelaku Ekonomi Percaya Bahwa Penguasaan Akan Dunia Internet Memberikan Kemudahan Akses Dalam Berusaha. Setiap Pelaku Ekonomi Yang Dapat Menyandingkan Produknya, Baik Dari Segi Promosi Maupun Penjualan Produk Melalui Internet Akan Mendapatkan Keuntungan Yang Signifikan. Galbreath (1999) Mengemukakan Bahwa Abad 21 Ditandai Oleh Perubahan Terus Menerus Secara Konstan Dan Lebih Cepat. Hal Ini 
Menunjukkan Pola Perubahan Ekonomi Di Abad 21 Akan Bergerak Sangat Cepat. Setiap Pelaku Usaha Dapat Memasarkan Produknya Tanpa Mengenal Kawasan/ Daerah Pemasaran. Semua Produk Dapat Dipasarkan Secara Global (Mendunia). Hal Ini Menyiratkan Bahwa Untuk Dapat Eksis Di Tengah Persaingan Semua Pelaku Ekonomi Harus Meningkatkan Efisiensi Pemanfaatan Sumber Daya Seoptimal Mungkin, Yang Dapat Bersaing Dengan Pelaku Ekonomi Dari Negera Berbeda.

Galbreath (1999) Menyatakan Delapan Perubahan Yang Dapat Terjadi Dalam Bidang Ekonomi Di Abad 21, Yaitu: Globalisasi, Pembiasaan Masyarakat, Perdagangan Produk, Pengurangan Biaya, Pengurangan Staf, Penekanan Pelayanan Konsumen, Kompleksitas Proses Bisnis, Dan E-Commerce. Perubahan Ini Terlihat Dari Keinginan Setiap Individu Pemakai Jasa Ekonomi (Barang Dan Jasa) Yang Ingin Dipermudah Ketika Membutuhkan Sesuatu Hal, Baik Itu Kebutuhan Akan Barang Maupun Jasa. Setiap Pelaku Ekonomi Harus Dapat Meletakkan Bisnisnya Pada Keistimewaan-Keistimewaan Tertentu Yang Diperoleh Pelanggan Ketika Menggunakan Barang/Jasa Mereka.

Pelaku Ekonomi Sebagai Pemilik Bisnis Harus Dapat Menemukan Sumber Daya Manusia Yang Mumpuni Dalam Menggunakan Internet. Bisnis Tidak Lagi Dilakukan Secara Perorangan Berdasarkan Batas Wilayah/Negara Tetapi Dilaksanakan Secara Serentak Melalui Jaringan Internet. Hal Ini Membuka Peluang Pekerjaan Kepada Tamatan-Tamatan Perguruan Tinggi Untuk Mengasah Keterampilan Internet, Sesuai Kebutuhan Pelaku Ekonomi. Setiap Tamatan Akan Mendapatkan Ruang Yang Sama Dalam Memasuki Dunia Usaha Baru, Yakni Sebuah Dunia Usaha Baru Yang Serba Cepat, Instan, Dan Berbasis Teknologi Informasi (Internet).

\section{HASIL dan PEMBAHASAN PENELITIAN}

Peran Pendidikan Dalam Pembangunan

Arti Pendidikan Berasal Dari Bahasa Inggris Yaitu Education, Dimana Dari Bahasa Latinnya Yaitu Eductum. Dengan Artian Kata "E" Yaitu Sebuah Proses Perkembangan Dari Dalam Keluar Kemudian Kata "Duco" Dengan Artian Yang Sedang Berkembang. Atau Dapat Diartikan Bahwa Pendidikan Adalah Suatu Proses Kemampuan Atau Keahlian Seseorang Yang Berkembang Terus Menerus Secara Individual.

Menurut Kamus Besar Bahasa Indonesia (Poerwadarminta, 2009), Pendidikan Diartikan Sebagai Sebuah Proses Ataupun Tahapan Dalam Pengubahan Sikap Serta Etika Maupun Tata Laku Seseorang Atau Kelompok Dalam Orang Dalam Meningkatkan Pola Pikir Manusia
Melalui Pengajaran Dan Pelatihan Serta Perbuatan Yang Mendidik. Dengan Kata Lain, Melalui Pendidikan Seseorang Dapat Mengembangkan Dirinya Sendiri Maupun Memberikan Manfaat Bagi Lingkungan Sekitarnya, Termasuk Pembangunan Di Daerahnya.

Peranan Pendidikan Dalam Proses Pembangunan Menjadi Arah Tujuan Bagi Pengambil Kebijakan Dalam Pengembangan Kebijakan Pendidikan. Bukti-Bukti Menunjukkan Adanya Kaitan Yang Erat Antara Pendidikan Formal Seseorang Dan Partisipasinya Dalam Pembangunan. Pemerintah Sedapat Mungkin Menjadikan Pendidikan Sebagai Engine Of Growth, Yaitu Pengerak Pembangunan. Sebagai Pengerak Pembangunan, Pendidikan Harus Mampu Menghasilkan Invention Dan Innovation. Dengan Harapan, Invention Dan Innovation Yang Dihasilkan Harus Dapat Membantu Masyarakat Memenuhi Kebutuhan Tenaga-Tenaga Terampil Melek Teknologi.

Penciptaan Tenaga-Tenaga Terampil Melek Teknologi Menjadi Tugas Setiap Lembaga Pendidikan, Khususnya Para Tingkat Perguruan Tinggi. Setiap Perguruan Tinggi Harus Mengarahkan Pola Pembelajaran Di Bangku Perkuliahan Dengan Menyasar Visi Pendidikan Abad 21. Unesco Memberikan Gambaran Jelas Paradigma Pendidikan Abad 21 Dalam Empat Visi Pendidikan: Learning To Think, Learning To Do, Learning To Live Together, Dan Learning To Be. (Sidi, 2001) Pola Learning To Think, Mengharuskan Perguruan Tinggi Mengarahkan Mahasiswanya Untuk Terus Berpikir. Dimana Berpikir Dimulai Dari Menerima Materi Dari Dosen Lalu Mengembangkan Materi Dari Buku Teks Dan Media Internet. Dengan Belajar Berpikir, Setiap Mahasiswa Memiliki Pengetahuan Yang Benar Akan Sesuai Hal Yang Dipelajarinya.

Learning To Do, Mengharuskan Perguruan Tinggi Mengarahkan Setiap Mahasiswa Menerapkan Pengetahuan Yang Dimiliki Dalam Kehidupannya. Setiap Pengetahuan Yang Dimiliki Mahasiswa Harus Dapat Dimanfaatkan Semaksimal Mungkin Untuk Mempermudah Penyelesaian Permasalahannya Di Masyarakat. Dengan Kata Lain, Pengetahuan Yang Dimiliki Memiliki Nilai Guna Bagi Dirinya. Learning To Live Together, Mengharuskan Perguruan Tinggi Mengarahkan Setiap Mahasiswa Dapat Menjalani Hidup Bersama-Sama Anggota Masyarakat Secara Tenteram. Setiap Mahasiswa Harus Dapat Menerapkan Sikap Toleransi Hidup Secara Bersama Sesuai Aturan/ Nilai-Nilai Hidup Di Masyarakat. Learning $\mathrm{To} \mathrm{Be}$, Mengharuskan Perguruan Tinggi Mengarahkan Mahasiswanya 
Untuk Terus Belajar Menjadi Dirinya Sendiri. Setiap Ilmu Pengetahuan Dan Keterampilan Yang Diperoleh Dari Perguruan Tinggi, Harus Dapat Dimanfaatkan Semaksimalnya Tanpa Menghilangkan Pribadi Terbaik Yang Dimiliki. Setiap Mahasiswa Harus Berjalan Sesuai Dengan Aturan Masyarakat Dan Menjalani Kehidupan Secara Baik Dan Beragama.

\section{KESIMPULAN}

Tantangan Pembangunan Pendidikan Adalah Meningkatkan Pelayanan Pendidikan Berkualitas Untuk Menciptakan Sumberdaya Manusia Sesuai Tuntutan Zaman. Berdasarkan Uu No. 20 Tahun 2003 Mengenai Sistem Pendidikan Nasional Dalam Pasal 3, Bahwa Tujuan Pendidikan Nasional Adalah Mengembangkan Potensi Peserta Didik Agar Menjadi Manusia Yang Beriman Dan Bertakwa Kepada Tuhan Yang Maha Esa, Berakhlak Mulia, Sehat, Berilmu, Cakap, Kreatif, Mandiri, Dan Menjadi Warga Negara Yang Demokratis Serta Bertanggung Jawab. Untuk Itu, Setiap Perguruan Tinggi Penghasil Sumberdaya Manusia Harus Mengarahkan Pembelajarannya Untuk Mencapai Tujuan Pendidikan Nasional, Salah Satunya Menciptakan Sumberdaya Manusia Yang Berilmu, Cakap, Dan Kreatif Sesuai Tuntutan Abad 21 Tanpa Menghilangkan Identitas Aslinya Sebagai Seorang Pribadi Beriman Dan Bertakwa Kepada Tuhan Yang Maha Esa.

Upaya Menciptakan Sumberdaya Manusia Yang Mumpuni Membawa Setiap Perguruan Tinggi Mengarahkan Pola Pembelajaran Berpedoman Pada Visi Pendidikan Abad 21. Visi Pendidikan Abad 21 Sesuai Arahan Unesco Meliputi: Learning To Think, Learning To Do, Learning To Live Together, Dan Learning To Be. (Baskoro, 2009) Untuk Itu, Menjadi Keharusan Setiap Pengajar Melakukan Inovasi Pembelajaran Yang Mengarahkan
Mahasiswa Pada Belajar Berpikir, Berbuat, Hidup Bersama, Dan Belajar Untuk Hidup Sesuai Pengetahuan Dan Keterampilan Yang Dimilikinya.

Setiap Tamatan Perguruan Tinggi Harus

Dapat Menyandingkan Produk Yang Dihasilkannya Baik Barang Atau Jasa Dengan Memanfaatkan Teknologi Informasi. Hal Ini Bertujuan Untuk Menyelaraskan Langkah Usaha Tamatan Sesuai Pergerakan Abad 21 Yang Bergerak Sangat Cepat Dengan Bercirikan Pemanfaatan Teknologi Informasi. Tamatan Perguruan Tinggi Harus Dapat Menghasilkan Produk Yang Kompoten Dan Berdaya Saing Tinggi Tanpa Mengenal Kawasan/ Daerah Pemasaran.

\section{DAFTAR PUSTAKA}

Baskoro, A.P. 2009. Mempersiapkan Generasi Di Abad 21. (Online), (Http://Baskoro.Blogspot.Com/2009/06/ Mempersiapkan-Generasi-Diabad-21Html/, Diakses 20 Januari 2020).

Galbreath J. 1999. Preparing The $21^{\text {st }}$ Century Worker: The Link Between Computer Based Technology And Future Skill Sets. Educational Technology

Poerwadarminta, Wjs. 2009. Kamus Besar Bahasa Indonesia. Jakarta: Balai Pustaka

Sidi, I.D. 2001. Menuju Masyarakat Belajar: Menggagas Paradigma Baru Pendidikan. Jakarta: Paramadina.

Susilo, H. 2011. Bended Learning Untuk Menyiapkan Mahasiswa Hidup Di Abad 21. Universitas Negeri Malang. Seminar Nasional Pengembangan Pembelajaran Berbasis Blended Learning.

Tilaar, H.A.R. 2002. Membenahi Pendidikan Nasional. Jakarta: Rineka Cipta

Undang-Undang No. 20 Tahun 2003 Tentang Sistem Pendidikan Nasional 